DOI: $10.1515 / \mathrm{rpp}-2015-0063$

Doctor of Pedagogical Sciences, Full Professor, NATALIYA MUKAN Lviv Polytechnic National University, Ukraine Address: 12 Stepan Bandera St., Lviv, 79013, Ukraine E-mail: nmukan@polynet.lviv.ua

Senior Instructor, SVITLANA KRAVETS

Lviv Polytechnic National University, Ukraine Address: 12 Stepan Bandera St., Lviv, 79013, Ukraine E-mail: s.f.kravets@gmail.com

\title{
METHODOLOGY OF COMPARATIVE ANALYSIS OF PUBLIC SCHOOL TEACHERS' CONTINUING PROFESSIONAL DEVELOPMENT IN GREAT BRITAIN, CANADA AND THE USA
}

\begin{abstract}
In the article the methodology of comparative analysis of public school teachers, continuing professional development (CPD) in Great Britain, Canada and the USA has been presented. The main objectives are defined as theoretical analysis of scientific and pedagogical literature, which highlights different aspects of the problem under research; characteristic of the research methodology, used to conduct the comparative analysis. Their major components of the research model (parametric-determining, conceptual and analytical, integrating-analytical and differentiating-analytical, prognostic component) have been defined and specified. Public school teachers' CPD has been studied by foreign and domestic scientists: political, social, cultural and economic aspects of teachers' $C P D$ (L. Darling-Hammond, M. Tight); CPD programs (C. Pratt); CPD content (N. Dana Fichtman, M. Rees, A. Ross, S. Zepeda); CPD models, methods and forms (K. Duinlan, P. Grimmet, G. Troia, P. Wong); continuous professional education (Ya. Belmaz, A. Kuzminskyy, O. Kuznyetsova). The research methodology comprises theoretical (comparative-historical, logical, induction and deduction, comparison and compatibility, structural and systematic, analysis and synthesis, general scientific and interdisciplinary forecasting methods), and applied (observations, questioning and interviewing) methods. The research results have been presented.

Key words: methodology, research model, comparative analysis, public school teachers, CPD, Great Britain, Canada, the USA.

\section{INTRODUCTION}

Nowadays particular attention and importance are given to education and training of people to prepare them for effective work and life in the contemporary knowledge-based society. The major task of public school is to prepare students for being ready to face challenges of economic, social, multicultural character arising in everyday life. Special attention is paid to the professional competency of teachers whose work is one of the most significant factors promoting improvement of students' achievements. The necessity of teachers' continuing professional development, for them to be able to provide high-quality educational services and to improve the work of public schools, is emphasized.

The study and analysis of the experience of teachers' professional development organization in other countries is an important source of information, necessary for
\end{abstract}


determining strategic directions of developing systems of continuing pedagogical education in Ukraine in the scopes of which teachers' professional development is realized. Great Britain, Canada and the USA are the countries that play a leading role in the international educational environment. Researchers in education of these countries constitute the expert core of international educational organizations, which develop documents and recommendations concerning the major principles and quality of pedagogical education and teachers' professional development, in particular. These countries have substantial pedagogical achievements and developed systems of continuing pedagogical education in the context of which the teachers' professional development is realized, the theory and practice of professional development being determined by their historical development, social progress, national traditions, with the account of the features of international educational environment. These are countries making substantial investments into the development of their education systems, understanding that this will guarantee social stability and increase of the well-being of their citizens and the very countries. One of the proofs of the highquality educational services provided by the teachers in the systems of school education in the countries being studied is active participation of their students in various international contests, subject competitions, programs as well as their ability to enter the world's most prestigious higher education institutions after leaving public schools. The countries' governments provide incentives to improve the quality of pedagogical activities through adopting national programs, developing special projects, working out standards of the teaching profession and teachers' professional development, increasing financing for their training as well as intensifying scientific research in the sphere of teachers' professional development etc.

\section{THE AIM OF THE STUDY}

The presentation of the methodology of comparative analysis of public school teachers' CPD in Great Britain, Canada and the USA is the research aim. The authors have defined the following objectives: 1) to conduct the analysis of scientific and pedagogical literature, which highlights different aspects of the problem under research, and 2) to present the methodology used in comparative analysis of public school teachers' CPD in the countries under research.

\section{THEORETICAL FRAMEWORK AND RESEARCH METHODS}

Professional development is regarded as a continuing process of lifelong learning and development, the process starting at the initial stage of one's life, continuing at a higher school and after graduating from it (Dugger, 2003) as well as various activities in which teachers are participating individually or collectively with the aim of improving professional skills or encouraging students to study (Sparks, Hirsh, 2000). This is the general complex of formal and informal learning experience being formed in the course of the entire career from pre-service pedagogical education to retirement (Fullan, Steigelbauer, 1991). Professional development foresees improving teachers' professionalism based on mastering professional knowledge, forming professional awareness and attitudes, development of skills, and competency (Evans, 2008). It is just the very process by which teachers are mastering and developing their own knowledge, skills of working with children, students, colleagues at every stage of their professional careers (Day, 1999).

As A. Glatthorn states, professional development is the development of a teacher's personality in the professional context through accumulating experience and systematic analysis of one's own pedagogical activities (Glatthorn, 1995). Professional development foresees acquiring formal and informal experience (Ganser, 2000): formal (for example, participation in workshops, professional meetings, mentorship) and informal experience 
(reading, publications, watching thematic documentary TV programs), the analysis of which determines the content of professional development, its operational component and the context in which it is realized (Ganser, 2000). Such a concept defines professional development of a teacher as the development occurring in the process of teacher's movement according to career cycle development (Glatthorn, 1995). Professional development is a complex of activities conducted on a systematic basis with the aim to prepare teachers for their professional activities and embraces initial training, induction programmes, in-service training, continuing professional development in school environment (Scheerens, 2010). "Professional development is defined as activities that develop an individual's skills, knowledge, expertise and other characteristics as a teacher" (OECD, 2009).

A complex of theoretical methods has been used as the basis of the research: comparative-historical method that allowed to study educational documents, normativelegislative regulations and laws on education, scientific and pedagogical literature, curricula and syllabi; logical method used to discover objective regularities for creating a set of concepts and judgments in the field of public school teachers' CPD; induction and deduction used for gathering theoretical and factual material, its generalization as well as realization and interpretation of separate phenomena of pedagogical reality; the method of comparison and compatibility that allowed to define similarities and differences in the process of teachers' professional development in the countries being studied and to reveal the tendencies of this process development in the international educational environment; the structural and systematic method used for considering structural elements and functional peculiarities of the systems of continuing pedagogical education of Great Britain, Canada and the USA; analysis and synthesis used for specifying content, models, methods and forms of teachers' CPD, for forming theories and hypotheses explaining specifics of its implementation; general scientific and interdisciplinary forecasting methods used for justifying introduction of effective ideas into the process of providing teachers' CPD in Ukraine.

The following empirical methods have been used: observations, questioning and interviewing teachers for gathering primary pedagogical information; interviewing and surveying research and teaching staff, administrative staff and students of educational departments, workers of teachers' associations and federations in Great Britain, Canada and the USA for clearing out specifics of organizing collaboration with schools; attendance of lectures and discussions on pedagogical topics with participants of educational process; personal participation in workshops organized by Alberta Teachers' Association (Canada); implementation and examination of a manual and monographs.

\section{RESULTS}

In our research, teachers' professional development is regarded as a continuing process embracing three components: initial training, induction and a permanent improvement of personal, social and professional competences of a teacher and it coincides with the teacher career cycle.

During comparative analysis of the systems of continuing pedagogical education in the countries being studied with the aim to avoid divergences and discrepancies in terminology there have been singled out two unified levels of defining teachers' professional development: systematic and procedural:

-teachers' professional development is a many-faceted phenomenon, its main characteristics correspond to a holistic, dynamic and open system, the major attributes of which are an appropriate structure, goal and objectives, content, methods and forms that are directed at mastering professional knowledge, development of competences from the initial 
stage of professional pedagogical training through teacher career cycle as well as implementation of the system of mastering competences;

-teachers' professional development is a process that embraces professional training at a higher educational institution, induction and continuing improvement of teacher's competences through teacher career cycle, its goal being providing professional, spiritual (mental) and physical development of a teacher who is a creator of educational environment in the XXI century where his/her world outlook principles of educational and cognitive activities are realized.

Comparative and pedagogical research of public school teachers' CPD in Great Britain, Canada and the USA is performed using the following concepts: analytical (characteristics of the systems of continuing pedagogical education in Great Britain, Canada, and the USA), critical (dynamics of functioning and reforming systems of continuing pedagogical education in the discourse of public school teachers' CPD), prognostic (application of effective ideas and experience of the researched countries in Ukrainian pedagogical theory and practice), and mechanisms of unification and diversification of the information obtained as the result of studying the normative-legislative base, scientific and pedagogical literature.

The characteristics of the research concept are:

- integration of acmeological, axiological, andragogical, anthropological, intercultural, competence, constructivist, systematic, structural-functional approaches;

- logics of constructing research quest that is based on principles of plurality, polyphony, uniqueness and combines parametric-determining, conceptual-analytical, integration-analytical, differential-analytical, prognostic components;

- complex application of cognitive-pedagogical models of humanitarian knowledge (the scientific research model of comparative-pedagogical investigation of public school teachers' CPD in Great Britain, Canada and the USA, the model of unification and the model of diversification of teachers' professional development in Great Britain, Canada and the USA according to dominant traits);

-structuring the scientific research information with singling out programs of professional development that integrate scientific approach, cognitive flexibility, generative character that ensure cognitive diversity and creativity of teacher's pedagogical activities.

The major points of the concept are reflected in the prognostic idea of the research, the basis of which is the assumption that to ensure efficiency of teachers' professional development in the system of continuing pedagogical education is possible if its content and operational components are based on the standards of professional development, harmonious combination of theory and practice of the pedagogical profession and satisfy actual demands and interests of teachers as competent specialists in the field of education prepared to work in the contemporary society.

The philosophic paradigm of humanitarian studies, positions on unity of general and specific, unified and unique, principles of unity of theory and practice, continuous, versatile and harmonious development of a personality, theory of scientific cognition, research education, epistemology of knowledge, proactive and context-situational professional training in interdisciplinary and transdisciplinary subject field, concepts of education democratization and humanization, dialogue character of cognition and selfknowledge, ideas of pedagogical prognostics form the methodological basis of the research. The following approaches have been singled out as the basic research-cognitive approaches: modeling as a cognitive mechanism; research of objects and phenomena with respect to 
their structure; study of the reality in the context of information processes; analysis of the interaction of a person with the reality.

In the course of the research there have been substantiated methodological fundamentals of comparative pedagogical research structured in the scientific research model of comparative pedagogical research of public school teachers' CPD in Great Britain, Canada and the USA that is based on significant semantic information on systems of continuing pedagogical education in these countries and is meant for logical presentation of its components in the context of their interrelation and for determination of common features and identification of the specifics of teachers' professional development in each of the countries (see Fig. 1).

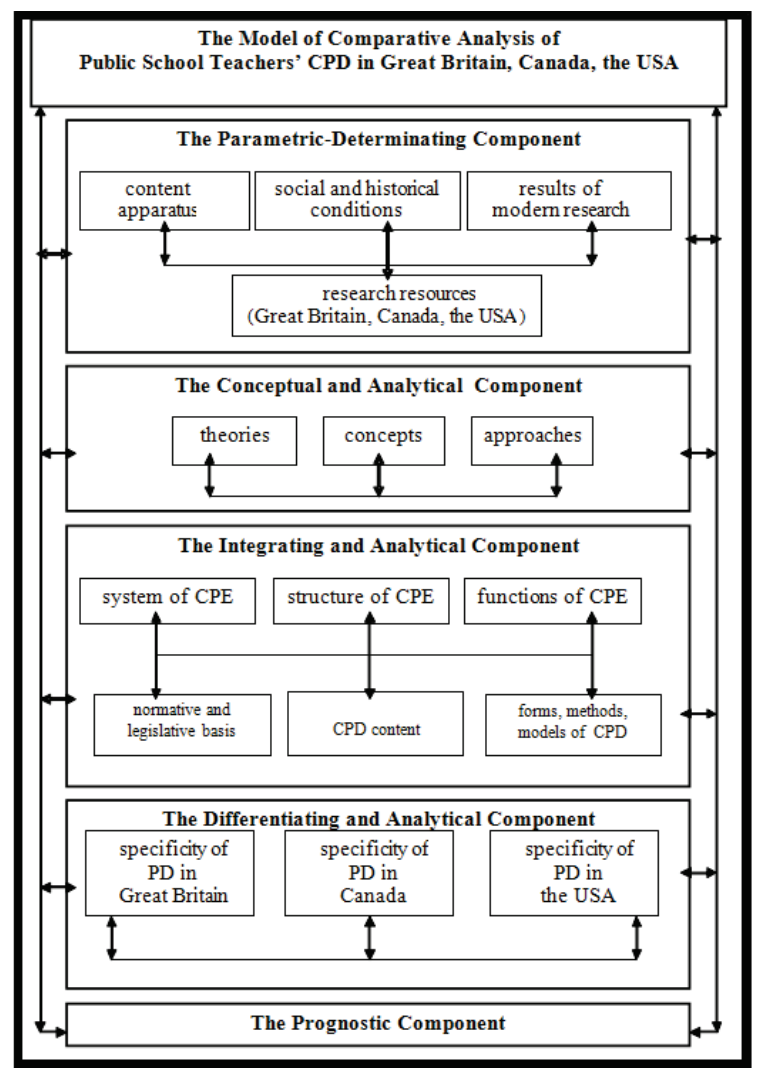

Fig. 1. The Model of Comparative Analysis of Public School Teachers' CPD in Great Britain, Canada, the USA

In accordance with the parametric-determining component the conceptual apparatus of the research; social and historical conditions and results of modern research into the issue of teachers' professional development; the resource base of public school teachers' CPD in the three countries have been studied and specified.

According to the conceptual and analytical component of the scientific research model of comparative-pedagogical research of public school teachers' CPD in Great 
Britain, Canada and the USA the phenomenon of professional development has been studied with the account of philosophic, psychological and pedagogical theories, concepts and approaches.

In the context of integrating-analytical and differentiating-analytical components of the scientific research model there have been established common and specific characteristics of public school teachers' CPD on the basis of the analysis of the following components: systems of continuing pedagogical education in the countries being researched; structural and functional characteristics of the systems of continuing pedagogical education; normative and legislative bases; content and operational components of professional development.

The prognostic component of the scientific research model envisages prognostics with respect to ensuring professional development of Ukrainian teachers on the basis of applying foreign experience in the field.

The algorithm of the research implementation reflects functional and consequential study of the teachers' professional development on the basis of applying the component structure of the scientific research model:

- stage I - defining the parametric-determining component;

-stage II - determining the conceptual and theoretical component;

- stage III - implementing the integrating and analytical research component with the aim of determining common characteristics of the researched phenomenon in Great Britain, Canada and the USA;

-stage IV - implementing the differentiating and analytical component for formulating specifics of the phenomenon in every of the researched countries;

- stage $\mathrm{V}$ - performing the prognostic component of the research model: development of scientific methodical recommendations concerning application of effective ideas and experience of the researched countries. development:

Three perspectives were taken into account while studying teachers' professional

- a person as an individual who is learning continuously;

- curricula based on the principle of continuity of teachers' educational activities with the aim to satisfy the needs and interests at different stages of their life;

-structural and functional organization of professional development in the system of continuing pedagogical education involving a network of educational institutions and their cooperation directed towards creating a complex of educational services based on principles of consistency, systematic character, continuity etc.

\section{CONCLUSIONS}

The beginning of the XXI century is characterized by new demands concerning all-round continuing development of a person. To ensure competitiveness and social development of a country primary attention is given to lifelong education, education of adults, the role and value of knowledge and skills of citizens as well as to high professional competence. Thus, the results of the research done allowed to make the following conclusions according to the tasks set.

Methodological foundations defining the directions and algorithm of the research realization are reflected in the research model of comparative-pedagogical research of public school teachers' CPD that is grounded on important semantic information on theory and practice of professional development and the system of continuing pedagogical education in conditions of which it is realized. Methodology of scientific analysis is based 
on functional combination of the following approaches: parametric and determining, conceptual and analytical, integrative and analytical, differential and analytical, prognostic. Models of unification and diversification of public school teachers' CPD in Great Britain, Canada and the USA present methodological tools the application of which made it possible to determine common characteristics and specifics of teachers' professional development in every country.

Prospects for future research include the development of the model of unification of teachers' professional development and the model of diversification of teachers' professional development in the systems of continuing pedagogical education of Great Britain, Canada and the USA by the dominant trait that allows to formulate their common and specific features.

\section{REFERENCES}

1. Day, C. (1999). Developing Teachers: the Challenges of Lifelong Learning. London : Routledge, $264 \mathrm{p}$.

2. Dugger, W., Meade, Sh., Delaney, L., Nichols, C. (2003). Advancing Excellence in Technological Literacy. Arlington: Phi Delta Kappa, Inc, 316 p.

3. Evans, L. (2008). What is Teacher Development and How is It Achieved Ontological and Processual Models. Issues in European Teacher Development: The European Conference on Educational Research: Linking Theory and Practice, September 10-12, 2008. Sweden : Gothenburg, $11 \mathrm{p}$.

4. Fullan, M., Steigelbauer, S. (1991). The New Meaning of Educational Change. $\left(2^{\text {nd }} e d\right)$. New York : Teachers College Press, $326 \mathrm{p}$.

5. Ganser, T. (2000). An Ambitious Vision of Professional Development for Teachers. NASSP Bulletin, No 84 (618), pp. 6-12.

6. Glatthorn, A. (1995). Teacher Development. In : Anderson, L. (Ed.), International encyclopaedia of teaching and teacher education, pp. 41-45.

7. OECD. (2009). Creating Effective Teaching and Learning Environments: First Results from TALIS. Paris : OECD, $309 \mathrm{p}$.

8. Scheerens, J. (2010). Teachers' Professional Development. Europe in International Comparison. An Analysis of Teachers' Professional Development Based on the OECD's Teaching and Learning International Survey (TALIS). Luxembourgh : Office for Official Publications of the European Union, 204 p.

9. Sparks, D., Hirsh, S. (2000). Strengthening Professional Development. Education Week, No 19 (37), pp. 42, 45. 